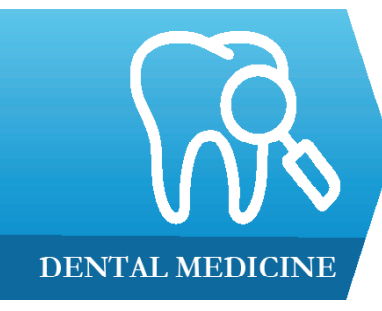

1) Department of Periodontology and Implantology, Karnavati School of Dentistry, Karnavati University, Gandhinagar, Gujarat, India

2) Department of Physiology, Karnavati School of Dentistry, Karnavati University, Gandhinagar, Gujarat, India
DOI: $10.15386 / \mathrm{mpr}-1213$

Manuscript received: 14.10 .2018

Received in revised form: 28.12 .2018 Accepted: 31.01 .2019

Address for correspondence: drsantoshkumar2004@gmail.com

\title{
A clinical and radiographical comparison of buccolingual crestal bone changes after immediate and delayed implant placement
}

\author{
Viraj Amin ${ }^{1}$, Santosh Kumar ${ }^{1}$, Surabhi Joshi ${ }^{1}$, Tanvi Hirani ${ }^{1}$, \\ Deepak Shishoo ${ }^{2}$
}

\begin{abstract}
Aim. The study aims to clinically and radiographically compare the bucco-lingual crestal bone changes after immediate and delayed placement of implants.

Methods. Two groups that consisted of fifty implants were considered for this study. In group A the implants were placed immediately post extraction, whereas, in group B implants placement were delayed by four to six weeks. All the implants were submerged within the alveoli confines. Bone grafts were only placed if the jumping distance was more than $1.5 \mathrm{~mm}$. Barrier membrane was not placed in any of the cases. Bucco-lingual width was measured at the time of implant placement and during abutment placement after four to six weeks. Primary flap closure was ensured in all the cases.
\end{abstract}

Results. Thirty-one implants were placed in the mandible and nineteen were placed in the maxilla. All the implants achieved osseointegration. Immediate implant group showed a mean width of $8.80 \mathrm{~mm}(\mathrm{SD} 2.280)$ at the time of implant placement whereas, $7.60 \mathrm{~mm}$ (SD 1.871) after six months. Delayed implant group showed a mean width of $8.40 \mathrm{~mm}$ (SD1.673) at the time of implant placement, and $7.40 \mathrm{~mm}$ (SD 1.658) after six months. Intragroup showed statistically significant data $(\mathrm{P}<0.05)$. When the intergroup comparison of group 1 and group 2 was made at implant placement day and abutment placement day, it was found to be statistically non-significant.

Conclusion. This study suggests that circumferential defect heals on itself without any guided bone regeneration in both the groups. The data suggests that the healing in both the group were equally good. The equally good results suggest placing the implant immediately post extraction. This saves the cost, time and most importantly the need for an extra surgery.

Keywords: bone loss, bone regeneration, dental implants, healing, peri-implants

\section{Introduction}

Oral disability caused by edentulism has been an ordeal for humankind for a very long time. The goal of the modern dentistry is to restore the patient to standard contour, function, comfort, aesthetics, speech and health whether by removing caries or by replacing missing teeth through any means including implants. Schulte and Heimke first described immediate implants in 1976 [1] in a clinical report.
The immediate implant is designed to prevent bone resorption following extraction. With this method, the ridge dimension and height are maintained and some surgical procedures omitted, shortening the healing period. Several research papers conclude that placing implants at the time of extraction of teeth may provide many advantages, such as maintaining crest height and width, reducing the number of surgeries, reducing treatment time, and excellent 
esthetic results [2-14]. Numerous studies have shown a high rate of clinical success $[2,11,15-17]$.

The peri-implant defect is classified into three categories according to morphology: no-wall defect, three wall defects, and circumferential defects [1]. Threewall and no wall defect represents the socket wall not in approximation with the implant surface, whereas later includes implants not contacting bone at their coronal surface. In these implants stabilization solely depends on the apical bone. In these cases, membrane and grafts have been advised [7,10,18-30]. Barrier membrane prevents the connective tissue to migrate between the implant and bone surface, whereas grafts help in the stability of the blood clot thereby favoring bone regeneration by osteogenic cells. Grafting could, moreover, enhance the tent effect by posing as space maintainer and promoting osteogenesis [21-23].

On the other side, numerous authors have experienced a high percentage of membrane exposure and infection (39\% to $41 \%)$ [15,24-26]. This membrane exposure to the oral fluids increases the risk of bacterial infection and hence, impaired bone formation $[7,8,24]$. Thus, delayed implants are promoted as it obtained better flap management over barrier membranes [27]. Delayed implants are placed three to four weeks or four to 12 weeks after extraction. They exhibit a lower frequency of soft tissue dehiscence in the membranebased regeneration when compared to immediately placed implants [28] Optimal bone healing is achieved due to undisturbed clot and possibly because of complete flap closure. Therefore, the above complications of barrier membrane restrict its usage.

An extensive study has also been done with the bone graft filling the peri-implant space. Researchers have shown that immediate implants, when treated with bone graft, have shown a high survival rate [29]. A critical histological study by Cochran et al. [30] showed less bone gain in sites treated with barrier membrane than in sites treated without a membrane. Histological section showed the same quality of osseous formation in all the samples [30]. Many authors have achieved positive results using demineralized, freeze-dried bone allograft (DFDBA) $[20,31,32]$.

This study is a comparative clinical and radiographical study which includes implants placed immediately after tooth extraction (Immediate implant) and the implants placed after 6-10 weeks of healing period post extraction, comparing bucco-lingual crestal bone changes.

\section{Materials and method}

This study was conducted at our dental institute with the institutional ethical clearance no KU/KSD/562.
The following formula were used to determine sample size.

$$
n=\left(Z_{\alpha / 2}+Z_{\beta}\right)^{2} * 2 * \sigma^{2} / d^{2}
$$

(Where $\mathrm{Z}_{\alpha / 2}$ is the critical value of the Normal distribution at $\alpha / 2)$.

It consisted of 50 subjects, 28 males and 22 females, with age ranging from 22 to 40 years. The mean age was 34.3 years at the time of the study. Patients who needed extraction and replacement with dental implant prostheses in anterior and premolar region and gave informed consent were selected for this study. Indications for extraction included tooth fracture, untreatable caries, endodontic failure, periodontitis or any other reason for hopeless prognosis. Patients who exhibited any systemic or local factors that could impair the osseointegration of the alveolar bone were excluded from the study. All the sites having $<5 \mathrm{~mm}$ of bone were also excluded. The research was performed following the Declaration of Helsinki of the world medical association (2008).

A total of 50 patients were equally divided into two groups. Immediate implants were placed in group A whereas Group B consisted of the patients who were delayed by 6 to 8 weeks for implant placement in order to get a complete soft tissue coverage over the placed implant. Treatment planning included clinical examination, photographs, recording of plaque index [33], gingival index [34], early wound healing index [35] and Computed cone beam tomography (CBCT) in every patient.

\section{Surgical procedure}

A mucoperiosteal flap was raised concerning the tooth to be extracted. All the necessary efforts were made to avoid trauma to the crestal bone during extraction. Extracted sites were drilled as per manufacturer's instructions (Seven, MIS, Shlomi, Israel) to prepare for implant placement. Once the preparation was completed, the corresponding size implant was placed within the alveoli and was made stable. After implant placement, the distance from the buccal bone to lingual bone was measured by using a bone calliper (BC35, GDC, India) and probe (EastView ${ }^{\mathrm{TM}}$ Paradise Dental Technology, Missoula, MT 59808) positioned perpendicular to the long axis of the implant. Grafts were only placed if the jumping distance was more than $1.5 \mathrm{~mm}$ while the membranes were not used in any of the cases. If primary closure was not attained, a horizontal periosteal incision was made, the flap was mobilized coronally and sutured with the help of 0-3 black silk suture. Medications were prescribed to all the patients, and it included Amoxicillin in combination with clavulanate potassium (Augmentin, 
Smithkline Beecham, Philadelphia, PA.) with a dose of 2 $\mathrm{g}$ four times daily for five days and Diclofenac Sodium (Agile, Ind-Swift Limited, IND) $50 \mathrm{mg}$ three times daily as the need for discomfort. For the esthetic reason, a temporary prosthesis was fabricated which did not compress the healing sites.

Second stage surgery was executed post six months to remove the cover screw in order to place the abutment. All the clinical parameters and CBCT readings were re-recorded by the same examiner as in the first stage to avoid inter-examiner bias.

\section{Statistical analysis}

All buccal to lingual crest measurements were recorded twice (first stage surgery and second stage surgery), and the difference in width was averaged. Relative mean, median, and Standard deviation were calculated for both the groups. The statistical significance of intragroup was calculated by paired t-test while inter group significance was derived by unpaired t-test.

\section{Results}

The total number of teeth involved in this study was fifty. Out of the fifty extractions, twenty were extracted due to root caries, four for periodontal reasons, five for residual roots, fifteen for endodontic treatment failures and remaining six for root fractures. Thirty-one implants were placed in mandible and nineteen were placed in the maxilla. All the implants were successful with no mobility. Plaque score, gingival index score, and early wound healing index score improved significantly at the second surgery.
At the time of implant placement mean distance from buccal to lingual crestal bone was $8.80 \mathrm{~mm}$ (SD 2.280 ) and $7.60 \mathrm{~mm}$ (SD 1.871) at the time of abutment placement in group 1, CBCT reading showed $8.50 \mathrm{~mm}$ (SD 2.240) and $7.20 \mathrm{~mm}$ (SD 2.310) respectively. Both data showed a significant change. No complications occurred during the healing period of six months (Table I). Group 2 showed a mean width of $8.40 \mathrm{~mm}$ (SD1.673) and $7.40 \mathrm{~mm}$ (SD1.658) at zero and six months respectively. CBCT reading showed a mean width of $8.14 \mathrm{~mm}$ (SD1.810) at implant placement day and 7.10 $\mathrm{mm}$ (SD1.580) at abutment placement day. Both the data showed a significant difference (Table I).

At implant placement day, mean width was 8.80 $\mathrm{mm}$ (SD 2.280) and $8.40 \mathrm{~mm}$ (SD 1.670) of group 1 and group 2 respectively, and this data was non-significant when compared (Table II). At the second stage surgery, all implants were found to be clinically osseointegrated. No peri-implant defects were observed. At this stage when group 1 and group 2 was compared, showed a nonsignificant change. At this stage, mean bucco-lingual crestal bone width was $7.60 \mathrm{~mm}$ (SD 0.049) for the group 1 and $7.40 \mathrm{~mm}$ (SD 0.041) for group 2. CBCT reading showed $7.20 \mathrm{~mm}$ (SD 2.231) for the group 1 and $7.10 \mathrm{~mm}$ (SD 1.580) for group 2 (Table II). Clinical photographs of two cases are presented in Figure 1 and 2. Intragroup comparison first to second surgery was statistically significant $(\mathrm{P}<0.05)$ as per the paired sample t-test. The difference in bucco-lingual bone width between immediate and delayed at the stage 1 surgery and stage 2 surgery were non-significant (Table II). The pattern of bone formation was clinically similar in both groups.

Table I. Intra Group clinical and radiographical comparison (Bucco-lingual width) of immediate and delayed implants at first surgical day versus second by Paired t Test.

\begin{tabular}{l|c|c|c} 
& $\begin{array}{c}\text { Implant } \\
\text { placement day }\end{array}$ & $\begin{array}{c}\text { Abutment } \\
\text { placement day } \\
\text { (at 6 Month) }\end{array}$ & P Value \\
Significance
\end{tabular}

Table II. Inter Group clinical and radiographical comparison (Bucco-lingual width) of immediate and delayed implant by unpaired t Test.

\begin{tabular}{|c|c|c|c|c|}
\hline & $\begin{array}{c}\text { Group } 1 \\
\text { Immediate implant }\end{array}$ & $\begin{array}{c}\text { Group } 2 \\
\text { Delayed placement }\end{array}$ & P Value & Significance \\
\hline Implant Placement Day (Clinical Reading in mm) & $8.80 \pm 2.280$ & $8.40 \pm 1.673$ & 0.4828 & NS \\
\hline Implant Placement Day (CBCT Reading in $\mathrm{mm}$ ) & $8.50 \pm 2.240$ & $8.14 \pm 1.810$ & 0.5349 & NS \\
\hline $\begin{array}{l}\text { Abutment placement Day (At } 6 \text { Months) } \\
\text { (Clinical Reading in mm) }\end{array}$ & $7.60 \pm 1.871$ & $7.40 \pm 1.658$ & 0.6909 & NS \\
\hline $\begin{array}{l}\text { Abutment placement Day (At } 6 \text { Months) } \\
\text { (CBCT Reading in } \mathrm{mm} \text { ) }\end{array}$ & $7.20 \pm 2.231$ & $7.10 \pm 1.580$ & 0.8557 & NS \\
\hline
\end{tabular}




\section{Dental Medicine}

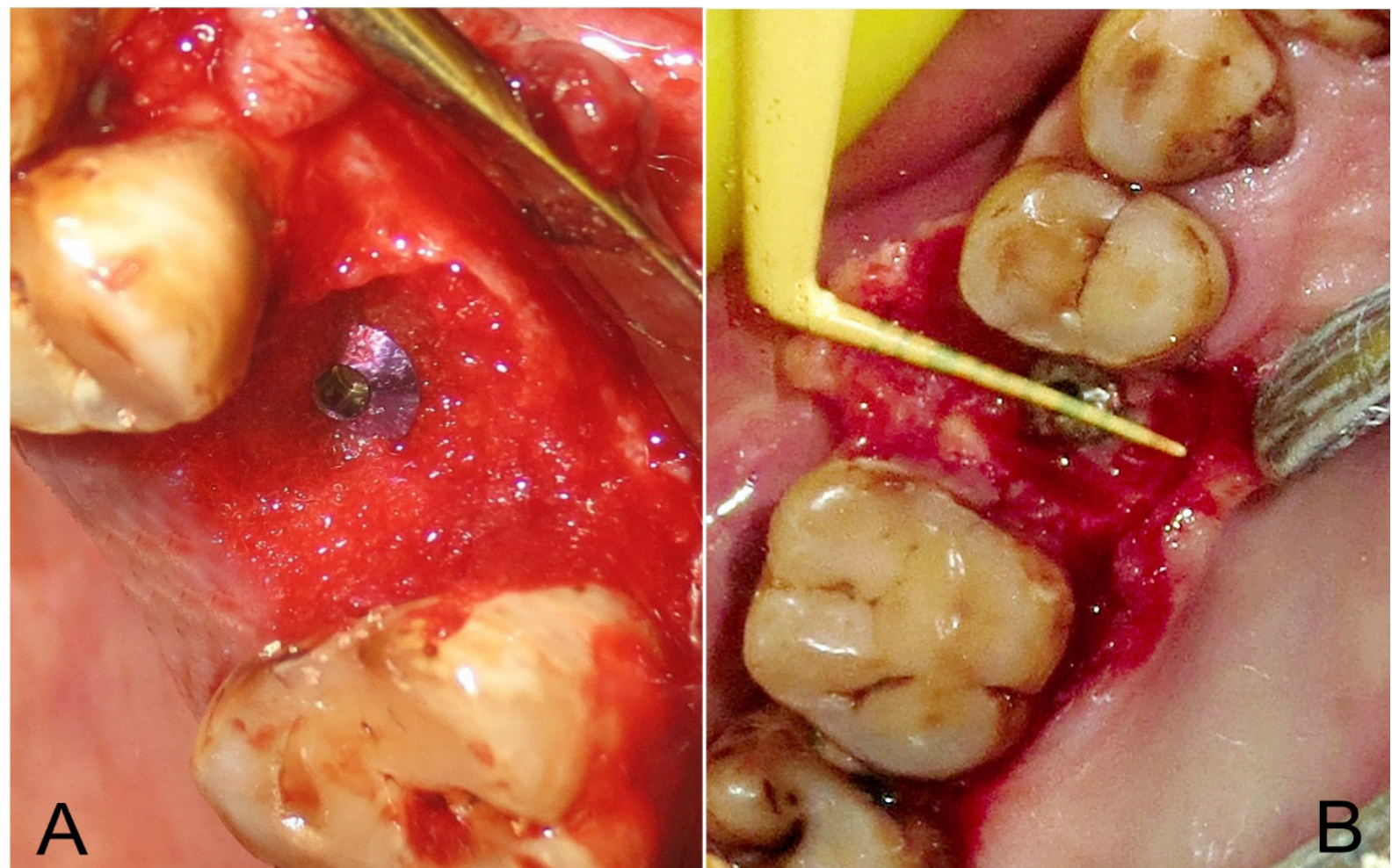

Figure 1. Implants placed immediately post extraction: (A) first surgery (B) Second surgery.

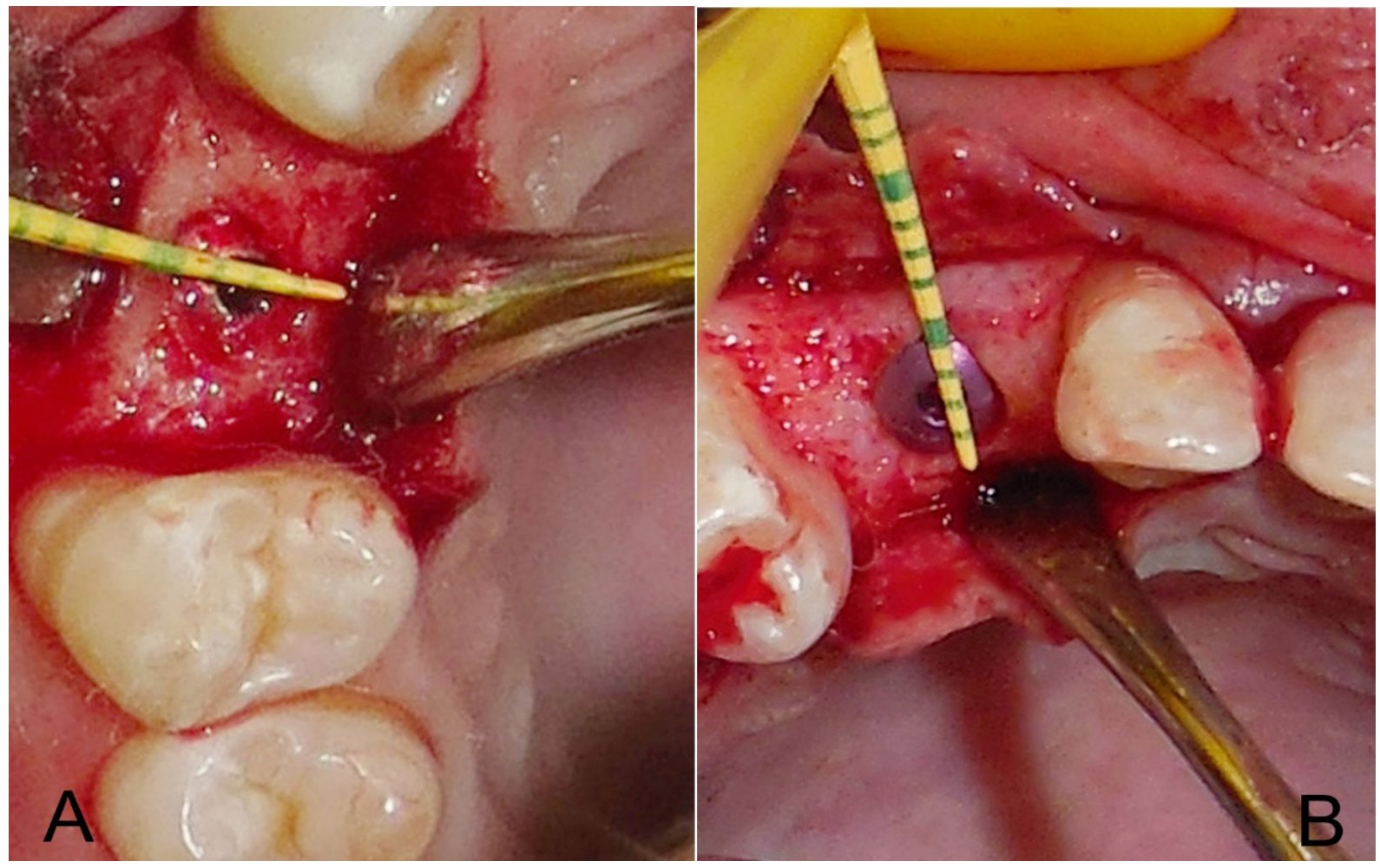

Figure 2. Implants placed six weeks post extraction: (A) first surgery (B) Second surgery. 


\section{Discussion}

There are strict protocols which facilitate osseointegration of immediate implant placement in infected extraction socket in a more liable mode. Some of the protocols include proper case selection, atraumatic extraction, prophylactic antibiotic administration, adequate osteotomy for primary stability [36]. Ayangco et al. in a study proposed that cases of retrograde peri-implantitis have been thought to result from placement into such sites [37]. In the presence of periapical infection, the immediate implant procedure should be avoided $[38,39]$. Chronic periodontitis is one of the risk factors associated with implant failure [40]. Siciliano et al. in his study concluded that insufficient soft tissue closure is also associated with immediate implant placement [41]. This clinical experience has led most clinicians to avoid the immediate placement of endosseous dental implants at infected sites and to consider infection a contraindication for immediate implantation. According to Schroop and Wenzel et al. [42], late placements may not be advisable. Late placement is usually associated with a buccolingual ridge reduction of about $50 \%$ of the initial ridge width over a 12-month period, and two-thirds of this bone remodelling takes place during the first three months of healing. Evian et al. [43] has reported concomitant vertical bone remodelling of 3 to $4 \mathrm{~mm}$ - approximately $50 \%$ of the initial socket height at six months post-extraction. Therefore, late implant placement in healed sites is not always recommended, as this may eventually necessitate advanced bone augmentation procedures.

An alternative treatment possibility that should be considered is delayed implant placement [6], which allows for the resolution of acute infection and increases the soft tissue level, ensuring better flap adaptation. This will prevent the substantial alveolar bone remodelling that occurs in fully healed sites. It is true that the evidence for the predictability of nonconventional (immediate or early) implant placement appears to be affected partly by the heterogeneity of studies concerning the implant site, timing, the location of the implant in the socket, bone wall defects, and augmentation procedures.

This study aimed to compare and analyze the clinical and radiographic bone healing around the immediate and delayed placed implants preferably without any graft or barrier membrane. Many of the authors have suggested the compulsory use of graft and barrier membrane for a complete formation of bone $[25,44,45]$. On the contrary, many have not suggested the use due to a significant problem in their application. Many studies have shown a high percentage of barrier membrane exposure leading to the complication in bone healing [46-49]. A study by Nowzari and Slots [25] showed the importance of complete flap closure and intern obtaining adequate bone. A review of literature by Jordi Ortega-Martínez et al. [50] stated the importance of primary stability with good predictable results in immediate implant placement. However, he laid importance on good case selection.

In the present study, only three implants got exposed one-month post placement, but the exposure did not lead to any complication or bone formation. On clinical observation, it did not appear statistically significant from its non-exposed counterpart. A study by Kahal et al. described a high frequency of membrane exposure during the healing period in immediate implants. This exposure leads to lower bone regeneration. This same result has been confirmed by Haas et al. [47] and Wilson et al [7].

In second surgery all the implants were clinically stable, healthy, and free from any bony defect. Previous works of literature have shown excellent healing in immediate implant placement without the use of barrier membrane or bone graft [5,29], and this study is no exception to it. A seven-year study conducted by SchwartzArad and Chaushu [29] reported a very low frequency of complication during the healing period. Becker and coworkers also reported a low-frequency failure rate of $6.7 \%$ in a four-year study of immediately place implants without any barrier membrane or grafts. The present clinical findings, following much data in previous researches, seems to support that the main factors necessary to induce bone healing are the primary stability of the implant, bony walls capable of stabilising clot, and primary flap closure. The use of membrane and grafting are questionable since all the implants in the present study healed without the use of it.

Contrary to the above finding Wilson et al. [7] in a study showed that the width of the circumferential gap is critical for the final amount of bone contacting the implant. He concluded that the bone filling was reduced if jumping distance exceeded $1.5 \mathrm{~mm}$. Moreover, an animal study by Pluemsakunthai $\mathrm{W}$ et al. [51] showed that $3 \mathrm{~mm}$ is the optimal gap distance among the groups examined, which drastically influences the healing of bone and soft tissue surrounding the implants. However, even a barrier membrane could not guarantee a perfect outcome.

The result of this study demonstrated uneventful healing in both the groups. No clinical differences in findings were recorded throughout the study. These findings confirm other reports of no clinical or radiographic differences in the healing of immediate and delayed implants. The pattern of coronal bone remodelling, showing a narrowing of the buccolingual width, was clinically similar for the two groups, although it should be noted that the delayed implants exhibited smaller buccolingual bone width already at the first measurement: it can be speculated that early remodelling may start immediately after tooth extraction and continue, non-uniformly, even after delayed implant placement. The crestal bone loss and buccolingual ridge alterations occurring in delayed implants are found to be similar when compared to the bone loss found in immediate implants. These findings are in accordance with the study performed by Covani et al [52]. The vertical 
dimension was not investigated in this study as horizontal osseous formation is more important than the vertical, in the extracted socket.

Before drawing any conclusion, it should be noted that a large sample size would have been preferable with a long-term follow-up. We have not taken into consideration both the single and multi-rooted teeth, but the postextraction healing sequel is different for both these teeth, which may be a limiting factor of this study. Though there are various studies in support of this study, it would be inappropriate to draw any firm conclusion related to this.

\section{Conclusion}

Although the cases dealt in this study are not numerous, the data suggest that the healing in both group are equally good. Hence, we should opt for the immediate placement of the implants. It will preserve the bone and prevent the collapse of the gingival architecture. It also reduces the treatment cost, time, preserves the gingival esthetics, and increases the comfort of the patients.

\section{References}

1. Schulte W. The intraosseous A12O3 (Frialit) Tuebingen implant. Developmental status after eight years (II). Quintessence Int. 1984;15:19-35.

2. Gelb DA. Immediate implant surgery: three-year retrospective evaluation of 50 consecutive cases. Int J Oral Maxillofac Implants. 1993;8:388-399.

3. Rosenquist B, Grenthe B. Immediate placement of implants into extraction sockets: implant survival. Int $\mathrm{J}$ Oral Maxillofac Implants. 1996;11:205-209.

4. Schwartz-Arad D, Chaushu G. The ways and wherefores of immediate placement of implants into fresh extraction sites: a literature review. J Periodontol. 1997;68:915-923.

5. Becker W, Clokie C, Sennerby L, Urist MR, Becker BE. Histologic findings after implantation and evaluation of different grafting materials and titanium micro screws into extraction sockets: case reports. J Periodontol. 1998;69:414421.

6. Schwartz-Arad D, Chaushu G. Immediate implant placement: a procedure without incisions. J Periodontol. 1998;69:743750 .

7. Wilson TG Jr, Schenk R, Buser D, Cochran D. Implants placed in immediate extraction sites: a report of histologic and histometric analyses of human biopsies. Int $\mathrm{J}$ Oral Maxillofac Implants. 1998;13:333-341.

8. Cornelini R, Scarano A, Covani U, Petrone G, Piattelli A. Immediate one-stage postextraction implant: a human clinical and histologic case report. Int J Oral Maxillofac Implants. 2000;15:432-437.

9. Kan JY, Rungcharassaeng K. Immediate placement and provisionalization of maxillary anterior single implants: a surgical and prosthodontic rationale. Pract Periodontics Aesthet Dent. 2000;12:817-824; quiz 826.

10. Rosenquist B, Ahmed M. The immediate replacement of teeth by dental implants using homologous bone membranes to seal the sockets: clinical and radiographic findings. Clin Oral Implants Res. 2000;11:572-582.

11. Schwartz-Arad D, Gulayev N, Chaushu G. Immediate versus non-immediate implantation for full-arch fixed reconstruction following extraction of all residual teeth: a retrospective comparative study. J Periodontol. 2000;71:923-928.

12. Chaushu G, Chaushu S, Tzohar A, Dayan D. Immediate loading of single-tooth implants: immediate versus nonimmediate implantation. A clinical report. Int $\mathrm{J}$ Oral Maxillofac Implants. 2001;16:267-272.

13. Paolantonio M, Dolci M, Scarano A, d'Archivio D, di Placido G, Tumini V, et al. Immediate implantation in fresh extraction sockets. A controlled clinical and histological study in man. J Periodontol. 2001;72:1560-1571.

14. Schultes G, Gaggl A. Histologic evaluation of immediate versus delayed placement of implants after tooth extraction. Oral Surg Oral Med Oral Pathol Oral Radiol Endod. 2001;92:17-22.

15. Becker W, Dahlin C, Becker BE, Lekholm U, van Steenberghe D, Higuchi K, et al. The use of e-PTFE barrier membranes for bone promotion around titanium implants placed into extraction sockets: a prospective multicenter study. Int J Oral Maxillofac Implants. 1994;9:31-40.

16. Huys LW. Replacement therapy and the immediate postextraction dental implant. Implant Dent. 2001;10:93-102.

17. Polizzi G, Grunder U, Goené R, Hatano N, Henry P, Jackson WJ, et al. Immediate and delayed implant placement into extraction sockets: a 5-year report. Clin Implant Dent Relat Res. 2000;2:93-99.

18. Lazzara RJ. Immediate implant placement into extraction sites: surgical and restorative advantages. Int J Periodontics Restorative Dent. 1989;9:332-343.

19. Becker W, Becker BE. Guided tissue regeneration for implants placed into extraction sockets and for implant dehiscences: surgical techniques and case report. Int J Periodontics Restorative Dent. 1990;10:376-391.

20. Mellonig JT, Triplett RG. Guided tissue regeneration and endosseous dental implants. Int J Periodontics Restorative Dent. 1993;13:108-119.

21. Stentz WC, Mealey BL, Nummikoski PV, Gunsolley JC, Waldrop TC. Effects of guided bone regeneration around commercially pure titanium and hydroxyapatite-coated dental implants. I. Radiographic analysis. J Periodontol. 1997;68:199-208.

22. Stentz WC, Mealey BL, Gunsolley JC, Waldrop TC. Effects of guided bone regeneration around commercially pure titanium and hydroxyapatite-coated dental implants. II. Histologic analysis. J Periodontol. 1997;68:933-949.

23. Nemcovsky CE, Moses O, Artzi Z, Gelernter I. Clinical coverage of dehiscence defects in immediate implant procedures: three surgical modalities to achieve primary soft tissue closure. Int J Oral Maxillofac Implants. 2000;15:843852.

24. Nowzari H, Slots J. Microbiologic and clinical study of polytetrafluoroethylene membranes for guided bone regeneration around implants. Int J Oral Maxillofac Implants. 1995;10:67-73. 
25. Augthun M, Yildirim M, Spiekermann H, Biesterfeld S. Healing of bone defects in combination with immediate implants using the membrane technique. Int J Oral Maxillofac Implants. 1995;10:421-428.

26. Machtei EE. The effect of membrane exposure on the outcome of regenerative procedures in humans: a metaanalysis. J Periodontol. 2001;72:512-516.

27. Artzi Z, Nemcovsky C. Bone regeneration in extraction sites. Part 1: The simultaneous approach. Implant Dent. 1997;6:175-181.

28. Watzek G, Haider R, Mensdorff-Pouilly N, Haas R. Immediate and delayed implantation for complete restoration of the jaw following extraction of all residual teeth: a retrospective study comparing different types of serial immediate implantation. Int J Oral Maxillofac Implants. 1995; 10:561-567.

29. Schwartz-Arad D, Chaushu G. Placement of implants into fresh extraction sites: 4 to 7 years retrospective evaluation of 95 immediate implants. J Periodontol. 1997;68:1110-1116.

30. Cochran DL, Schenk R, Buser D, Wozney JM, Jones AA. Recombinant human bone morphogenetic protein-2 stimulation of bone formation around endosseous dental implants. J Periodontol. 1999;70:139-150.

31. Urist MR, Strates BS. Bone formation in implants of partially and wholly demineralized bone matrix. Including observations on acetone-fixed intra and extracellular proteins. Clin Orthop Relat Res. 1970;71:271-278.

32. Shigeyama Y, D'Errico JA, Stone R, Somerman MJ. Commercially-prepared allograft material has biological activity in vitro. J Periodontol. 1995;66:478-487.

33. Turskey S, Gilmore ND, Glickman I. Reduced plaque formation by the chloromethyl analogue of victamine C. J Periodontol. 1970;41:41-43.

34. Lobene RR, Weatherford T, Ross NM, Lamm RA, Menaker L. A modified gingival index for use in clinical trials. Clin Prev Dent. 1986;8:3-6.

35. Watchel H, Schenk G, Böhm S, Weng D, Zuhr O, Hürzeler MB. Microsurgical access flap and enamel matrix derivative for the treatment of periodontal intrabony defects: a controlled clinical study. J Clin Periodontol. 2003;30:496504.

36. Narad C, Lingraj JB, Aulakh KK, Handa K, Kotrashetti SM, Pinto PX. Assessment of primary stability of the implant placed in prepared infected extraction sockets. J Oral Biol Craniofac Res. 2018;8:154-157.

37. Ayangco L, Sheridan PJ. Development and treatment of retrograde peri-implantitis involving a site with a history of failed endodontic and apicoectomy procedures: a series of reports. Int J Oral Maxillofac Implants. 2001;16:412-417.

38. Werbitt MJ, Goldberg PV. The immediate implant: bone preservation and bone regeneration. Int $\mathrm{J}$ Periodontics Restorative Dent. 1992;12:206-217.

39. Álvarez-Camino JC, Valmaseda-Castellón E, Gay-Escoda C. Immediate implants placed in fresh sockets associated to periapical infectious processes. A systematic review. Med Oral Patol Oral Cir Bucal. 2013;18:e780-e 785.

40. Evian CI, Emling R, Rosenberg ES, Waasdorp JA, Halpern
W, Shah S, et al. Retrospective analysis of implant survival and the influence of periodontal disease and immediate placement on long-term results. Int $\mathrm{J}$ Oral Maxillofac Implants. 2004;19:393-398.

41. Siciliano VI, Salvi GE, Matarasso S, Cafiero C, Blasi A, Lang NP. Soft tissues healing at immediate transmucosal implants placed into molar extraction sites with buccal selfcontained dehiscences. A 12-month controlled clinical trial. Clin Oral Implants Res. 2009;20:482-488.

42. Schropp L, Wenzel A, Kostopoulos L, Karring T. Bone healing and soft tissue contour changes following singletooth extraction: a clinical and radiographic 12-month prospective study. Int $\mathrm{J}$ Periodontics Restorative Dent. 2003;23:313-323.

43. Lekovic V, Kenney EB, Weinlaender M, Han T, Klokkevold $\mathrm{P}, \mathrm{Nedic} \mathrm{M}$, et al. A bone regenerative approach to alveolar ridge maintenance following tooth extraction. Report of 10 cases. J Periodontol 1997;68:563-570.

44. Wachtel HC, Langford A, Bernimoulin JP, Reichart P. Guided bone regeneration next to osseointegrated implants in humans. Int J Oral Maxillofac Implants. 1991;6:127-135.

45. Gotfredsen K, Nimb L, Buser D, Hjørting-Hansen E. Evaluation of guided bone generation around implants placed into fresh extraction sockets: an experimental study in dogs. J Oral Maxillofac Surg. 1993;51:879-884; discussion 885-886.

46. Celletti R, Davarpanah M, Etienne D, Pecora G, Tecucianu JF, Djukanovic D, et al. Guided tissue regeneration around dental implants in immediate extraction sockets: comparison of e-PTFE and a new titanium membrane. Int J Periodontics Restorative Dent. 1994;14:242-253.

47. Haas R, Baron M, Dörtbudak O, Watzek G. Lethal photosensitization, autogenous bone, and e-PTFE membrane for the treatment of peri-implantitis: preliminary results. Int J Oral Maxillofac Implants. 2000;15:374-382.

48. Dimitriou R, Mataliotakis GI, Calori GM, Giannoudis PV. The role of barrier membranes for guided bone regeneration and restoration of large bone defects: current experimental and clinical evidence. BMC Med. 2012;10:81.

49. Cucchi A, Vignudelli E, Napolitano A, Marchetti C, Corinaldesi G. Evaluation of complication rates and vertical bone gain after guided bone regeneration with non-resorbable membranes versus titanium meshes and resorbable membranes. A randomized clinical trial. Clin Implant Dent Relat Res. 2017;19:821-832.

50. Ortega-Martínez J, Pérez-Pascual T, Mareque-Bueno S, Hernández-Alfaro F, Ferrés-Padró E. Immediate implants following tooth extraction. A systematic review. Med Oral Patol Oral Cir Bucal. 2012;17:e251-e261.

51. Pluemsakunthai W, Le B, Kasugai S. Effect of buccal gap distance on alveolar ridge alteration after immediate implant placement: a microcomputed tomographic and morphometric analysis in dogs. Implant Dent. 2015;24:70-76.

52. Wilson GT, Weber HP. Classification of and therapy for areas of insufficient bony housing prior lo dental implant placement. Journal of Periodontology and Restorative Dentistry. 1993:13:451-459. 